РОЗДІЛ IV. ПОЛІТИЧНІ ІНСТИТУТИ ТА ПРОЦЕСИ

УДК 323.019.5(477)

Iryna Kiyanka,

National Academy of Public Administration under the President of Ukraine,

ORCID ID: 0000-0002-3100-7796

kiyanka@i.ua

DOI 10.29038/2524-2679-2020-02-184-191

\title{
THE CONCEPT OF POPULISM: A POLITICAL ASPECT OF DEMOCRATIC SYSTEMS
}

The article focuses on populism, a phenomenon topical in the socio-political life of many countries. While it has a significant influence on the politics of countries with relatively little experience of functioning democratic institutions, populism is quite clearly visible also in modern political space of the old democracies. There is a distinct link between exacerbation of socio-economic problems and increasing attractiveness of populism. An important factor contributing to the emergence and growth of populist influences is the inability of political establishments, including fully democratic ones, to respond effectively to changes and new challenges.

Key words: populism, ideology, political leader, charisma, political system, political regime, political movement, political party, transformational processes, postcommunism

\section{INTRODUCTION}

It is important today to understand the phenomenon of populism as it is becoming a characteristic feature of both Ukrainian and world politics. Populism poses a threat to democratic development of countries because under the banners of populism and through the use of the tools of democracy - power can be gained by persons who will reverse democratic practices. This has already occurred in the recent history of Ukraine and led to the emergence of two Maidans.

(C) Kiyanka I., 2020 
In the popular Ukrainian political lexicon of the independence years, the term «populism» is probably one of the most commonly used words. At the same time, it is likely the most popular accusation against government officials or political opponents. If the phrase is used in any domestic political controversy, it almost always implies that a particular proposal involves solutions (usually to socio-economic problems) that are seemingly attractive, but impossible to implement (Kiyanka, 2018, p. 5). Today the Ukrainian society is a fertile ground for populists as it is suffused with desire for «justice», which is understood as purifying the country of corruption and as an affirmation of greater social equality i.e. providing all people with access to basic social resources.

The purpose of the article is to analyze the concept of populism in the context of political systems and the development of democratic values as well as to overview the ideas of populism in the context of world experience (e.g. Ukraine, the US, Latin America and the CEE countries). The research methods include synthesis and comparison, as well as historical approach.

\section{CAUSES OF POPULISM}

Emergence of populism clearly coincides with similar leanings of the majority of the political elite and the sentiment of the general public. Dissatisfied with their economic situation, which sharply deteriorates particularly in times of war and crisis, citizens hope that reforms will be a way to improve the lives of the majority. For example, the reform benchmarks pursued by the Ukrainian authorities after the Euromaidan (and supported by Ukraine's international donors and strategic allies) have at their core a value choice that is substantially different from most Ukrainian citizens' concept of social justice. The implemented program of liberal market reforms is aimed at reducing social responsibility of the state, further privatization of state-owned enterprises (including energy and transport monopolies), timely payment of rather burdensome external financial obligations of Ukraine, etc. At the same time, the history of political struggle in Ukraine since 1991 has been, to a large extent, the story of a contest of generous populist socio-economic promises. That is why, in the author's opinion, the ideology of today's reforms contrasts dramatically with both the tradition of Ukrainian politics and the sentiment of the general public.

Considering the main socio-psychological aspects of populism, its social characteristics are shaped by education, family traditions and self-reflection, 
while the psychological ones - by media, rumors, and gossip. Depending on the correlation of these two aspects, a person is either immune or susceptible to populism (Betz, 1994, p. 72-74). Therefore, it is the responsibility of conscious citizens to promote democratic values and support their prominence in the media space as it is the media that play a major role in destruction and construction of values or pseudo-values.

Addressing populism as a category of political analysis leads to a conclusion that the issue is much more complex and multidimensional than its usage in media and political debates might suggest. In the scientific community, consensus on the understanding of populism has not been achieved yet, and researchers' approaches accentuate its different elements, thus embodying different views on the meaning of the term «populism». It can be perceived both as a political tool and a specific characteristic of political activity, as well as a socio-political phenomenon, or even an ideology (Panizza, 2005).

This text is an overview - by no means exhaustive - of the numerous and varied manifestations of populism noted in the history of the world. It is important to present the entire range of populist bids for power as due to the complexity, variegation and ambivalence of the phenomenon of populism, a simple case study would be inadequate. The research on populism is actualized by the presence of a social order from interested political actors, who use populism to implement their programs and as a tool in power struggle.

In many countries of Western Europe, the early 1990s saw the rise of modern-day populism. Today, the populist forces of what Donald Rumsfeld described as «old Europe» are characterized by (1) propensity for various forms of nationalistic rhetoric and ideology; (2) critical views on the EU and the processes of globalization; (3) negative attitude towards mass immigration. A specific new feature of Western European populism is the emergence of movements and politicians who, while being populist in their rhetoric and choice of political tools, advocate the principles of a free market, restriction of state regulation, and reduction of tax burden, often combining these goals with calls for protectionist policies (Lytvyn, 2015).

Examples of the connection between populism on the one hand and mass politics and democracy on the other can be found in the history of ancient Greece, which was a birthplace of the first democratic political system in Europe. An integral part of the political life of ancient Athens was the activity of individual demagogues, characterized by populist rhetoric, pronounced leaderism, and the ability to manipulate and direct the masses. 
In modern times, populism became an important dimension of political life in the 19th c., when in the context of the formation of democratic political institutions in Europe and America, the masses again became an active subject of political struggle. It emerged also in autocratic Russian empire, which at that time included the Ukrainian lands. One of the historical variants of populism was specifically called «populism»: it was a political movement and an ideology at the core of which was the belief that the peasantry was the bearer of all virtues and the basis for a just social system of the future. In a slightly modified form, the political legacy of populism was repurposed by Russian Bolshevism, facilitating the conquest of power by communists in a backward, then largely agrarian Russia (Novakova, 2015).

Many examples of populism can be found in the history of the United States, a country that has embarked on a path of democratic development since its inception. In the years 1820-1830, President Andrew Jackson was able to gain power and carry out far-reaching reforms by making distinctly populist appeals to the electorate and interpreting the presidential power in a populist manner as being a direct expression of the will of the people. Today populism is still a topical phenomenon in the political life of the US, a form of political activity among broad sections of the American society, and a significant factor influencing the party establishment. Donald Trump's election campaign of 2016 can serve here as an illustration.

In the 20th c. populist politics has become a powerful tool in the socioeconomic and political development of many Latin American countries. An example of this would be the Peronist movement in Argentine, where the oligarchic groups had prevented the lower classes as well as part of the educated middle classes from having any real influence on political decisionmaking. However, the oligarchy turned out to be unable to carry out the much needed modernization of the state; this led to the populist president Juan Peron coming to power. Relying on the relatively stable support of the broad Argentine masses, he was able to carry out significant reforms, introducing state regulation of the economy to ensure a more even distribution of national wealth. However, the downside of these changes included suppression of the opposition as well as violations of basic civil and political rights and freedoms.

Another, more modern model of leftist populist politics was the rule of Venezuela's President Hugo Chávez. It was an embodiment of the typical features of Latin American populism, including measures to regulate the economy, very vivid leaderism, anti-Americanism, the president (i.e. the 
«leader») appealing directly to the poorest, etc. It is important to note that in spite of the serious violations of democratic institutions during the populist regimes of Peron and Chavez, the foundations of a democratic system and political pluralism were not destroyed, generally ensuring the legitimacy of both presidents through at least sufficiently democratic procedures, as well as their electoral success (Mudde, 2013).

In Central and Eastern Europe, populism returned to the political scene at the turn of the 1990s, after the collapse of communist regimes. In this region radical reforms were introduced by political forces that based their program on the traditional ideological systems which had developed in the West over the past decades, using the «pre-socialist» political experience of their respective countries as well as renewed democratic tradition (Wasilewski, 2019). The results of changes in the social system differed from country to country. The rapid transformation of the socio-economic order was accompanied by considerable difficulties and problems, while the formation of a democratic political space opened the way for populists proposing easy solutions. In the countries of the former Soviet bloc, populism was predominantly nationalistic. However, for some time the efforts of the new elites in the CEE countries to integrate into pan-European structures - a policy that had the support of a stable majority of the population - hindered the spread of the anti-EU sentiments inherent among populists in Western European countries (Stekel, 2019).

Although what has developed in most of the post-communist countries is democratic rivalry of center-right and center-left forces, some CEE states have come too close to the point at which democracy transforms into authoritarianism. It happened in Slovakia with the regime of Vladimir Meciar, and in Hungary with the government of Viktor Orbán and Fidesz party (Zachara, 2019). In the latter country, the ruling party today combines nationalism with distinctly populist elements in its agitation and activities. Already in 2000, following a very successful transition to democracy and market economy, populism became a prominent factor in the political life of Poland - the most influential of all the former communist countries in Central and Eastern Europe. If the activity of Andrzej Lepper was a striking but marginal phenomenon in Polish politics, later populist strategies contributed to the success of the PiS government. Today, the ruling forces in Poland seek to actualize the nationalist and conservative political heritage (Romanyuk, 2013). Populist traits are also evident in the activities of the current President of the Russian Federation. While the efforts of the authorities in Russia's mainstream 
democratic institutions have become insubstantial, Vladimir Putin has built his own legitimacy within Russia's powerful imperial and authoritarian tradition. The country maintains at least the formality of election procedures - an obstacle somewhat preventing radical nationalists and fascist groups from rising to power - and that the regime does not fully control the modern electronic media, making use of their propaganda value; however, populist tools have been successfully used by the Russian president to bolster his mass support. It is symptomatic that recently in Europe favorable attitudes toward Russian politics are often expressed by those parties and politicians who have the most populist traits, usually combined with nationalist leanings.

The last part of this study focuses on the agenda of Ukrainian politics and a set of modern challenges faced by the state: the political system of Ukraine is undergoing a significant transformation which is influenced by European integration on the one hand, and by internal crisis and foreign policy pressures (e.g. in the form of a hybrid war) on the other. At a time of political, economic and ethnopolitical instability, populism is gaining influence, turning into a widely used political tool applied to ensure the achievement of short-term political goals.

In the history of independent Ukraine populism has manifested itself on a large scale and in different ways. Even before, in the years leading to the crisis of the socialist system that ultimately resulted in its collapse, it was political agitation (which, however, cannot be called populism yet) that helped the national-democratic forces to remove the communists from power. After Ukraine gained independence, significant elements of populism became a constant in the political struggle in the country. The actual standard for political competitions in Ukraine was to make generous yet unlikely social and economic promises - an approach adopted by most parties and politicians.

Ukrainian election races, especially the presidential ones, demonstrate another populist trait - attempts to represent political rivalry as a struggle between the forces of good and evil. This rhetoric reflects the deep cultural and mental differences between Ukrainian regions. Populist traits can be discerned in most of the significant Ukrainian political forces. For some, party ideology became a smokescreen to cover the interests of certain business groups ( $\mathrm{Rad}, 2010)$.

There is a clear need to reduce the level of populism in Ukrainian sociopolitical life, to weaken its influence on the process of power struggle and on government decisions (although these aspects may be relatively less burdened with populism than election campaigns). This could be facilitated by taking a 
number of measures, e.g. saturation of information spaces with objective analytical materials that would demonstrate the possible consequences of attempts to implement populist proposals, their harm or infeasibility. Such a space could be a media platform potentially capable of counteracting populism (Lisnychuk, 2018).

The author believes that the popular assumption about the connection between populism and democracy should be revised. The phenomenon of populism is not characteristic of democracy, but of mass politics - political activity in which large masses of citizens are involved as an active subject. The political struggle for democracy - understood here as a stable political system, founded on many established political institutions - can be considered as such a political activity.

\section{CONCLUSIONS AND PROSPECTS FOR FURTHER RESEARCH}

Generally speaking, after winning the elections, populists prioritize the destruction of democratic institutions, as it is tactically easier to achieve a goal when no deterrent system works. The next step involves violation or restriction of human rights, as the end justifies the means. Anti-populism in turn develops and cultivates qualified and responsible elitism, pluralism, diversity and tolerance, liberalism, public participation and responsibility with regard to public service and public good.

Incidentally, mobilization of those who have never gone to the polls or participated in decision-making and politics creates a nuclear electorate for true populist players (e.g. the case of Brexit). Therefore, public participation and inclusion are good defense against the encroachment of populism.

As a global phenomenon, neo-populism is (paradoxically) an anti-globalist trend that is spreading worldwide. Its appeal lies in challenging the world order and avoiding concerns about climate problems, the prospects of global economic crises, migration and its causes etc. - the state becomes a castle where the rulers can comfortably play with the moods of their own people. This pattern has become typical of many countries ruled by left-wing, right- wing or centrist populists.

As a countermeasure, it is necessary to build strong institutions, develop the middle class, provide quality education, support the intellectual elite, ensure citizen participation in political processes, preserve balanced media and increase their weight. 


\section{REFERENCES}

1. Betz, H.-G. (1994). Radical Right-Wing Populism in Western Europe. Houndmills, Basingstoke, Hampshire, and London: Palgrave Macmillan.

2. Kiyanka, I. (2018). Populism as a Challenge to Public Administration: Historical Aspect. DEMOCRATIC GOVERNANCE: Academic Papers Collection, 21. Retrieved from http://lvivacademy.com/vidavnitstvo_1/visnyk21/fail/Kijanka. pdf

3. Lisnychuk O. (2018). Populism in Ukraine: Theoretical Principles and Problems of Studying the Phenomenon. IF Kuras Institute for Political and EthnoNational Studies of NAS of Ukraine, 63-73. Retrieved from http://ipiend.gov. ua/wp-content/uploads/2018/07/lisnychuk_populizm.pdf

4. Lytvyn, V. (2015). Theoretical features, institutional risks and positives of balanced semi-presidentialism and prospects for its reform in Ukraine. Studia politologica Ucraino-Polonia, 5, 45-54. Retrieved from http://nbuv.gov.ua/UJRN/ Spup_2015_5_6

5. Marchart, O. (2007). Post-Foundational Political Thought: Political Difference in Nancy, Lefort, Badiou and Laclau. Edinburgh: Edinburgh University Press.

6. Mudde, C. (2013). Populism in Europe and the Americas. Cambridge: Cambridge University Press.

7. Novakova, O. (2015). Formation of a new ideology of political participation of Ukrainians. Studia politologica Ucraino-Polonia, 5, 194-200. Retrieved from http://nbuv.gov.ua/UJRN/Spup_2015_5_24

8. Panizza, F. (2005). Introduction. In Populism and the Mirror of Democracy. London; New York: Verso.

9. Rad, T. (2010). Populism as a product of political communication. Visnyk of Lviv National University. Series: Philosophical Sciences, 15, 287-296.

10. Romanyuk, A. (2013). Factors of formation and functioning of populism in Ukraine. In Z. Białobłocki, A. Romanyuk (Eds.), Rozwój polityczny państw Europy Środkowej i Wschodniej (p. 29-41). Kutno, Lviv: Wyższa Szkoła Gospodarki Krajowej w Kutnie. Ivan Franko National University of Lviv.

11. Stekel, M. (2019, Feb 8). Populism in the world and elections. What are the features of populism in Ukraine? Retrieved from https://www.radiosvoboda. org/a/29759648.html

12. Wasilewski, K. (2019). Hate speech and identity politics. An intercultural communication perspective. Przeglad Europejski, 3, 175-189.

13.Zachara, M. (2019). Can Institutions Save the Word? Neoliberal Institutionalist Perspective on Global Governance. Stosunki Międzynarodowe, 55(1), 41-59.

Матеріал надійшов до редакиії 08.12.2020 p. 